\title{
Multiple-year Protection of Ash Trees from Emerald Ash Borer with a Single Trunk Injection of Emamectin Benzoate, and Single-year Protection with an Imidacloprid Basal Drench
}

\author{
David R. Smitley, Joseph J. Doccola, and David L. Cox
}

\begin{abstract}
Green ash (Fraxinus pennsylvanica Marsh.) street trees ranging in size from 25 to $45 \mathrm{~cm}$ dbh were trunk injected with emamectin benzoate at rates of $0.10-0.60 \mathrm{~g}$ ai $/ 2.54 \mathrm{~cm}$ dbh at three Michigan, U.S., locations in 2005 or 2006. Tree health was monitored by annual canopy thinning and dieback ratings for up to four years after a single treatment. Branch samples were collected in the autumn and the bark removed to count emerald ash borer larvae for most treatments over the same period of time. A single trunk injection treatment of emamectin benzoate at the $0.1,0.2$, or $0.4 \mathrm{~g}$ ai rate gave $100 \%$ control of emerald ash borer larvae in 98 of 99 treated trees for 2-3 years. Canopy ratings for treated trees remained similar for 2-4 years following trunk injection, while $>50 \%$ of the control trees died during the same period of time. Ash trees that received a combination of an imidacloprid trunk injection and an imidacloprid basal drench or an annual imidacloprid basal drench had similar canopy ratings, but more larvae were found in branches from trees receiving the annual basal drench

Key Words. Agrilus planipennis; Ash; Emerald Ash Borer; Emamectin Benzoate; Fraxinus; Trunk Injection.
\end{abstract}

Emerald ash borer (EAB), Agrilus planipennis Fairmaire (Coleoptera: Buprestidae) is native to China, Korea, Taiwan, Japan, Russia, and Mongolia (Haack et al. 2002; Bray et al. 2007). It was first discovered in North America in 2002 after urban ash trees near Detroit, Michigan, U.S., were observed to decline and die at an unprecedented rate (Cappaert et al. 2005; Smitley et al. 2008). As of March 2010, EAB has been found in 13 U.S. states (Michigan, Ohio, Indiana, Illinois, Pennsylvania, Kentucky, Wisconsin, West Virginia, Maryland, Virginia, Missouri, Minnesota, and New York), and two Canadian provinces (Ontario and Québec) (USDA 2010). Unfortunately, EAB is causing nearly $100 \%$ mortality of ash (Fraxinus spp.) trees in any growing environment unless they are treated with efficacious insecticides (Cappaert et al. 2005; Poland and McCullough 2006; Smitley et al. 2008). As EAB continues to spread, an increasing number of municipalities and private property owners face difficult decisions about the removal of ash trees or investment in insecticide treatment of selected trees. Trunk injections of imidacloprid or emamectin benzoate, and basal soil applications of imidacloprid were adequately efficacious against emerald ash borer when applied every year, but little information is available on more than one year of control following a single treatment (Cappaert et al. 2005; Herms et al. 2009; Smitley et al. 2010). Up until this time, very few private property owners and a small proportion of municipalities have chosen to treat ash shade trees with insecticides, most likely because they believe insecticide treatments are more expensive than tree removal, or are not reliable for saving ash trees. During the past five years, trunk injections of emamectin benzoate have dramatically changed the cost/benefit analysis for treating ash trees to protect them from EAB. Data presented in this paper detail extremely efficacious and consistent protection over multiple years from a single application. This results in a lower annual cost than previous treatments, less injury to trees, and improved environmental safety because all of the insecticide is contained within the tree, with the exception of any residue that may be found in shed leaves (Kreutzweiser et al. 2008).

\section{MATERIALS AND METHODS}

Trunk injection of emamectin benzoate was evaluated for control of EAB larvae for 2-4 years following a single treatment of green ash (Fraxinus pennsylvanica Marsh.) street trees at three locations: Troy, East Lansing, and Adrian, Michigan. Emamectin benzoate treatments were compared with a control (nontreated) treatment at each location, and also with a standard treatment (imidacloprid trunk injection plus imidacloprid basal soil drench) at the Adrian site. Efficacy against EAB larvae was determined by collecting branch samples each autumn and removing the bark to count larvae and new galleries. Branches were pruned from the upper one-third of the tree canopy between September 15 and November 4 each year. Three branches, at least $1.0 \mathrm{~m}$ long and with a diameter between 4 and $12 \mathrm{~cm}$, were removed from each tree by city arborists using a bucket truck, while additional crew provided assistance from the ground. Branches in this size range were chosen because in previous surveys the greatest density of EAB larvae was found in branches with a diameter of $8-12 \mathrm{~cm}$ (Marshall et al. 2009). All of the trees in this study were healthy at the start of testing, dead branches were rarely encountered with the exception of the control trees. When the canopy thinning of control trees exceeded $65 \%$ in July, some branches of these trees were found to be entirely dead during branch sampling in autumn. In September and early October, dead branches were 
avoided by only sampling branches with live leaves. In late October or early November, after leaf abscission, dead branches in control trees were avoided by scraping a patch of bark before cutting a branch to make sure it was alive. In some cases when it was not possible to find three live branches, only one or two branches were sampled. If no live branches were found then the tree was excluded from branch sampling and the number of replications was reduced accordingly. The first live branch found in the upper one-third canopy with a diameter of 4-12 cm was removed, and the remaining two branches were chosen to be as far away as possible from the first branch, and from each other, to maintain canopy balance. Bark splits and emergence holes were not considered in branch sampling. Branch samples were dropped to the ground where side branches and twigs were removed.

The branches were bundled and labeled for transport to Michigan State University's Entomology Field Research Farm in East Lansing for processing. When branches were processed, a 0.65 $\mathrm{m}$-long section in the center of each branch was marked for scraping. The circumference of each branch was recorded at both ends of the scraped area. Surface area of each branch sample was determined by averaging the circumference of both ends, and using the formula for the surface area of a cylinder (L2 $\varpi \mathrm{R})$. EAB galleries and larvae were counted after clamping branch sections between the ends of a modified saw-horse and removing the bark with a drawknife and chisel. Branch samples were processed in a heated shed at the Entomology Field Research Farm. Annual canopy thinning and dieback ratings were made in July each year by comparing the canopy of each tree with photographs in various stages of decline from $0 \%$ (healthy) to $100 \%$ (dead) in $10 \%$ increments (Smitley et al. 2008). Each tree was rated by two or three individuals and averaged across observations to obtain an annual defoliation rating. When study trees were rated at $>90 \%$ canopy thinning and dieback in July, they were excluded from branch sampling, and the trees were removed by the city during the winter.

Treatment means were compared at each test site using the general linear models procedure (PROC GLM) of SAS 9.1 (SAS 2003). Levene's test was used as part of the GLM procedure to test for homogeneity of variance. Percent data were transformed to arcsine square root $(\mathrm{x})$ before analysis. Means were separated at the $P=0.05$ level using Tukey's option in the MEANS statement. This performs a Tukey's studentized range test (HSD) when group sizes are equal and a Tukey-Kramer test when group sizes are unequal (SAS 2003).

\section{Troy Site 2005-2006}

Street trees in a neighborhood in the northern part of Troy, MI, were used for this test. These trees were between 12 and 26-yearsold and ranged in size from $18-61 \mathrm{~cm}$ diameter at breast height (dbh). The mean dbh was $35.6 \mathrm{~cm}$. Trees in this test were planted and maintained by the City of Troy. The trees were located between the street and the sidewalk, and were spaced a minimum $15 \mathrm{~m}$ apart and in no case did they overlap. Tree trunks were measured and marked with a metal tag during the final two weeks of April 2005. Lawns in the neighborhood were well-maintained and received natural rainfall, but very few were irrigated. Trees were grouped into 10 blocks of six trees based on location in the neighborhood. Each treatment was replicated 10 times with each replicate consisting of an individual tree. The treatments at this site consisted of five rates $(0.10,0.20,0.40,0.48$, and 0.60 $\mathrm{g}$ ai/2.54 $\mathrm{cm} \mathrm{dbh)} \mathrm{of} \mathrm{emamectin} \mathrm{benzoate} \mathrm{formulated} \mathrm{by} \mathrm{Arbor-}$ jet, Inc. (Woburn, MA, U.S.) and Syngenta Crop Protection, Inc. (Greensboro, NC, U.S.) as a $4.0 \%$ ME. All trees receiving an emamectin treatment were trunk-injected on May 25, 2005 using the Arborjet Tree $\mathrm{IV}^{\mathrm{TM}}$ system. The formulated insecticide was diluted $1: 1$ with water and put into a bottle pressurized to $3.16 \mathrm{~kg} / \mathrm{cm}^{2}$ before being injected through four evenly spaced sites on the lower trunk of each test tree. All treated trees received a single trunk injection treatment on May 25, 2005, with the exception of trees receiving the $0.1 \mathrm{~g}$ ai $/ 2.54 \mathrm{~cm}$ rate, which were injected again May 23, 2006, at the same rate. Control trees were not injected or treated with any insecticide. Canopy thinning and dieback ratings were made for each tree on June 27, 2005, and June 15, 2006, as previously described. Upper branches were sampled using a bucket truck in October 2005, and the bark scraped as described.

\section{East Lansing Site, 2005-2009}

Green ash street trees in East Lansing, MI, between 14 and 28-yearsold with a trunk diameter between 25 and $61 \mathrm{~cm}($ mean $=35.6 \mathrm{~cm})$ were maintained by the City of East Lansing. Trees were located between the street and the sidewalk in seven different neighborhoods and spaced a minimum of $15 \mathrm{~m}$ apart to prevent canopy overlap. Tree trunks were measured and marked with a metal tag during the first week of August 2005. Study trees were located in well-maintained lawns, but very few were irrigated. Treatments were replicated 10 times with individual tree replicates. A description of each of the four treatments in this test follows, including the formulation, type of application, rate, and application date.

(1) TREE-äge (emamectin benzoate, Syngenta Crop Protection, Inc.) was applied once at $10 \mathrm{ml} / 2.54 \mathrm{~cm}$ dbh $(0.4 \mathrm{~g}$ ai) on September 27, 2005. To apply using the Arborjet Tree IV system, emamectin benzoate was diluted 1:1 with water and the solution was placed into a single pressurized $3.16 \mathrm{~kg} / \mathrm{cm}^{2}$ bottle connected to four injection needles. At four evenly-spaced distances around the trunk at a height of $20-40 \mathrm{~cm}$ above the ground, four holes were drilled into the sapwood and a plastic septum (Arborjet \#4 plug) was inserted, through which needles were placed for injection. (2) Emamectin benzoate was applied once in spring 2007 at $2.5 \mathrm{ml} / 2.54 \mathrm{~cm}(0.1 \mathrm{~g}$ ai $) \mathrm{dbh}$. Trunk injections were made with the Arborjet QUIK-jet ${ }^{\mathrm{TM}}$ micro-injector. The number of injection sites was determined by the formula: trunk $\mathrm{cm} \mathrm{dbh/5.08}$. Undiluted emamectin benzoate was injected in equal amounts through plastic septa. A rate of $0.1 \mathrm{~g}$ ai/ $2.54 \mathrm{~cm}$ dbh was injected on May 21, 2007. (3) Emamectin benzoate was trunk injected in spring 2007 at $5 \mathrm{ml} / 2.54 \mathrm{~cm}$ dbh $(0.2 \mathrm{~g}$ ai). Injections were made once on May 21, 2007 with the micro-injector as previously described. One tree was dropped from the test after the first year because the homeowner applied an additional insecticide treatment. (4) Control treatment, these trees were not treated.

Annually in early July, and as previously described, canopy thinning and dieback ratings were made for each tree. When branch sampling was included, the branches were pruned from the upper one-third of the tree canopy between September 19 and 26, 2006, October 8 and 12, 2007, or November 4 and 10, 2008. Branches were collected, the bark removed, and EAB larvae counted as previously described. 


\section{Adrian Site, 2006-2009}

Green ash street trees in Adrian, MI, between 14 and 28-years-old and from 15-65 cm dbh (mean dbh $=43 \mathrm{~cm}$ in 2008), were selected for this test. Test trees were located between the street and the sidewalk in five different neighborhoods. All of the green ash street trees in these neighborhoods were used in the study if they had at least a $15 \mathrm{~cm} \mathrm{dbh}$, appeared to be relatively healthy (less than $25 \%$ canopy thinning and dieback in September 2005), and were spaced at least $15 \mathrm{~m}$ apart. Tree trunks were measured and marked with a metal tag during the first week of September 2005. Study trees were located in low-maintenance lawns, and very few were irrigated. Each treatment was replicated 10 times with each replicate consisting of an individual tree. Four insecticide treatments and two control treatments were evaluated from June 2006 to July 2009. A description of each treatment follows, including the formulation, type of application, rate, and application date.

(1) Emamectin benzoate was applied once at $10 \mathrm{ml} / 2.54$ $\mathrm{cm}$ dbh $(0.4 \mathrm{~g}$ ai) on June 22, 2006. Trunk injections were made as previously described in the East Lansing test. (2) Emamectin benzoate, trunk injected as described in treatment (1). The only difference among these two treatments is that branch samples were collected and scraped to count larvae for treatment (1) but not for treatment (2).

Unlike the previous two studies sites, (3) Imidacloprid $75 \mathrm{WP}$, was applied as a basal drench at a rate of $1.42 \mathrm{~g}$ ai/2.54 $\mathrm{cm} \mathrm{dbh}$. Annual treatments consisted of the appropriate amount of imidacloprid mixed in 5.71 of water and poured around the base of the tree within $70 \mathrm{~cm}$ of the trunk on June 27, 2006, May 24, 2007, and June 3, 2008. (4) Imidacloprid 5\% SL, formulated by Arborjet and Bayer, was trunk-injected using the Arborjet Tree IV system at a rate of $0.2 \mathrm{~g} \mathrm{ai} / 2.54 \mathrm{~cm}$ trunk dbh. The formulated insecticide was diluted 1:1 with water and put into a bottle pressurized to $3.16 \mathrm{~kg} / \mathrm{cm}^{2}$ before being injected through four sites on the lower trunk of each test tree on June 22, 2006. In addition, trees in treatment (4) also received an imidacloprid basal drench at a rate of $1.42 \mathrm{~g}$ ai/2.54 cm dbh on June 6, 2007, and June 10, 2008. Trees in treatments (5) and (6) were left as untreated controls.

Canopy thinning and dieback ratings were made for each tree in early July of each year as previously described. Upper branches from trees in three treatments were collected between October 15 and 19, 2007. The bark was removed and EAB larvae counted as previously described.

\section{RESULTS}

Results from all three locations indicate a single trunk injection treatment of ash trees up to $45 \mathrm{~cm}$ dbh in size, made in May or June with emamectin benzoate at $0.1-0.4 \mathrm{~g}$ ai $/ 2.54 \mathrm{~cm}$ dbh consistently gives nearly $100 \%$ control of EAB larvae even under intense pressure from EAB. Control trees declined rapidly at test sites due to $\mathrm{EAB}$ infestation, going from canopy thinning ratings of $19 \%$ to $54 \%$ in one year at Troy, $15 \%$ to $58 \%$ in four years at East Lansing, and from $15 \%$ to $87 \%$ in three years at Adrian, while canopy thinning ratings for ash trees that were trunk-injected with emamectin remained similar throughout the test period.

The death and removal of some trees decreased the number of replications in the third and fourth year of this study at the East Lansing and Adrian sites. Two trees at the Troy site and one tree at each of the East Lansing and Adrian sites were prematurely removed by city arborists during the winter by mistake. The av- erage area of bark sampled per tree was $1067 \mathrm{~cm}^{2}$, and ranged from $691 \mathrm{~cm}^{2}$ to $3,741 \mathrm{~cm}^{2}$, depending on the size of the tree.

\section{Troy Site, 2005-2006}

Green ash street trees in Troy were of a uniform size at the beginning of the test in June $2005(29.2-30.5 \pm 6.5 \mathrm{~cm} \mathrm{dbh}$ ) (Table 1). Initial tree health ratings as measured by canopy thinning were also similar, with no differences among treatments with the exception of trees receiving the highest rate of emamectin benzoate. Ash trees in that treatment started the test in June 2005 with a significantly higher level of canopy thinning (41.5 $\pm 26.0 \%)$ compared with control trees $(19.0 \pm 14.7 \%)$. This happened despite a random assignment of trees to treatments.

All rates of emamectin benzoate $(0.1-0.6 \mathrm{~g}$ ai $/ 2.54 \mathrm{~cm} \mathrm{dbh})$ were extremely effective when applied as a trunk injection in late May 2005. No larvae were found in any of the branch samples (30 branch sections per treatment) collected in October 2005, despite evidence of a moderate level of EAB tunneling injury from the year before $\left(11.2\right.$ old galleries $\left./ \mathrm{m}^{2}\right)$ and intense pressure from EAB in 2005 (59.2 live larvae $/ \mathrm{m}^{2}$ in control trees). Complete protection of ash trees from the trunk injections of emamectin at all tested rates in May 2005 was expressed the following summer (July 2006) in canopy thinning ratings that were as good or better than the initial ratings in June 2005 (16.7\%-34.3\% canopy thinning). Meanwhile, control trees declined rapidly in response to the extensive damage caused by 59.2 larvae $/ \mathrm{m}^{2}$, deteriorating to a mean rating of $59.2 \%$ canopy thinning and dieback in June 2006 (Table 1).

\section{East Lansing Site, 2005-2009}

Trees in the East Lansing site were of similar in size (28-38 \pm $10 \mathrm{~cm} \mathrm{dbh}$ ) as those evaluated in Troy, but trunk injection treatments were initiated at an earlier stage of EAB infestation, when trees were still in excellent health based on average ratings of $7 \%$ to $17 \%$ canopy thinning (Table 2). EAB density increased four-fold in control trees from autumn 2007 to autumn 2008 , going from $6.9 \pm 9.4$ to $28.7 \pm 21.5$ larvae $/ \mathrm{m}^{2}$, respectively. In stark contrast, no larvae were found in branch samples collected from trees that were trunk injected with emamectin benzoate three years earlier at a rate of $0.4 \mathrm{~g}$ ai $/ 2.54 \mathrm{~cm}$ in September 2005. The same trees continued looking healthy through August 2009 , when they were rated as having $13.8 \pm 14.1 \%$ canopy thinning, compared to a mean rating of $58.1 \pm 33.2 \%$ for control trees (Table 2). Emamectin trunk injections made in May 2007 at the 0.1 or $0.2 \mathrm{~g} \mathrm{ai} / 2.54 \mathrm{~cm}$ dbh rate also provided excellent protection, with no EAB larvae being found in branches collected from treated trees in October 2007 or October 2008.

\section{Adrian Site, 2006-2009}

Green ash street trees in all treatments were healthy at the beginning of the test in July 2006 (14.2\%-16\% canopy thinning, Table 3). Trees in the two control treatments remained healthy in 2007 (10.3\%-12\% canopy thinning), but declined rapidly in 2008 (58.3\%-64 \% canopy thinning and dieback) in response to intense pressure from EAB. Nearly all the ash trees in both control treatments were dead by July $2009(84.6 \%-89.5 \%$ canopy thinning and dieback). During the same time period (2006-2009), trees that were trunk-injected with emamectin benzoate at $0.4 \mathrm{~g}$ ai/2.54 cm dbh in June 2006 remained healthy (Table 3). Trees 
receiving an annual basal drench of imidacloprid or a combination of imidacloprid basal drenches and an imidacloprid trunk injection also remained healthy during the test. Canopy ratings made in July 2009 and branch samples in October 2008 indicate ash trees receiving a single trunk injection of emamectin benzoate were well-protected for at least two years. Some EAB larvae were found in branch samples from one emamectintreated tree in October 2007, but no larvae were found in any samples from emamectin treated trees in October 2008 (Table 3).

\section{DISCUSSION}

The authors of the study did not determine how important adult mortality was compared with larval mortality for trunkinjected trees in this study. However, when the bark was removed from branches in September and October live larvae in the emamectin-treated trees were not found, while dead EAB larvae were rarely found, suggesting that adult mortality, reduced egglaying, and mortality of young larvae are the most likely mechanisms of EAB control. Also, no EAB larvae were located in emamectin-treated trees, even when the trees were surrounded by heavily infested ash $\left(28-45\right.$ EAB larvae $\left./ \mathrm{m}^{2}\right)$. It is likely that under these conditions some EAB females would fly from surrounding ash to deposit eggs on the study trees, yet no larvae in the emamectin treated trees were found. This suggests emamectin is toxic to EAB larvae that tunnel into treated trees.

Trunk injections of emamectin benzoate reduced the density of EAB larvae found in treated trees by nearly $100 \%$ compared with control trees at all three sites. In the longest-running test at the East Lansing site, a single trunk injection of emamectin benzoate at the $0.4 \mathrm{~g} \mathrm{ai} / 2.54 \mathrm{~cm}$ dbh rate applied to ash trees with a $41 \mathrm{~cm}$ dbh gave $100 \%$ control of EAB larvae for three years. This suggests ash trees of this size could be adequately protected by making a trunk injection treatment at the $0.4 \mathrm{~g}$ ai rate once every three or four years. Our results also showed trunk injections at the 0.1 or $0.2 \mathrm{~g}$ ai/per $2.54 \mathrm{~cm}$ dbh rate gave excellent protection of $38 \mathrm{~cm}$ dbh trees for two years. Ash trees could be protected with trunk injections made at the $0.1 \mathrm{~g}$ ai rate once every two years. This is half the amount of ai that would be required to treat trees once every four years at the 0.4 ai rate.

Table 1. Troy, Michigan: emerald ash borer larval density in green ash street trees and canopy thinning ratings of the same trees for 1.5 years after trunk injection of emamectin benzoate at rates of $0.10-0.60 \mathrm{~g} \mathrm{ai} / 2.54 \mathrm{~cm} \mathrm{dbh}$. Data are means $\pm S D$. Each treatment has 10 replications unless indicated otherwise under mean \pm SD as $(n)$.

\begin{tabular}{|c|c|c|c|c|c|}
\hline Treatment & $\begin{array}{l}\text { Treatment } \\
\text { Dates }\end{array}$ & $\begin{array}{l}2005 \\
\mathrm{dbh}(\mathrm{cm})\end{array}$ & $\begin{array}{l}2005 \\
\text { Canopy } \\
\text { thinning }(\%)\end{array}$ & $\begin{array}{l}2005 \\
\text { Larvae } \\
\text { per } \mathrm{m}^{2}\end{array}$ & $\begin{array}{l}2006 \\
\text { Canopy } \\
\text { thinning (\%) }\end{array}$ \\
\hline $\begin{array}{l}\text { Emamectin } \\
0.10 \mathrm{~g} / 2.54 \mathrm{~cm} \mathrm{dbh}\end{array}$ & $\begin{array}{l}5-25-05+ \\
5-23-06\end{array}$ & $30.0 \pm 3.6$ & $16.5 \pm 13.4 \mathrm{~A}$ & $0 \pm 0 \mathrm{~A}$ & $16.7 \pm 8.8$ \\
\hline $\begin{array}{l}\text { Emamectin } \\
0.20 \mathrm{~g} / 2.54 \mathrm{~cm} \text { dbh }\end{array}$ & $5-25-05$ & $30.0 \pm 3.6$ & $25.0 \pm 11.1 \mathrm{AB}$ & $0 \pm 0 \mathrm{~A}$ & $26.7 \pm 25.0$ \\
\hline $\begin{array}{l}\text { Emamectin } \\
0.40 \mathrm{~g} / 2.54 \mathrm{~cm} \mathrm{dbh}\end{array}$ & $5-25-05$ & $30.5 \pm 5.8$ & $30.8 \pm 22.1 \mathrm{AB}$ & $0 \pm 0 \mathrm{~A}$ & $28.2 \pm 27.9$ \\
\hline $\begin{array}{l}\text { Emamectin } \\
0.48 \mathrm{~g} / 2.54 \mathrm{~cm} \mathrm{dbh}\end{array}$ & $5-25-05$ & $26.4 \pm 6.4$ & $26.8 \pm 13.2 \mathrm{AB}$ & $0 \pm 0 \mathrm{~A}$ & $21.0 \pm 14.5$ \\
\hline $\begin{array}{l}\text { Emamectin } \\
0.60 \mathrm{~g} / 2.54 \mathrm{~cm} \text { dbh }\end{array}$ & $5-25-05$ & $30.4 \pm 6.5$ & $41.5 \pm 26.0 \mathrm{~B}$ & $0 \pm 0 \mathrm{~A}$ & $34.3 \pm 40.2(9)$ \\
\hline Control & - & $29.6 \pm 4.8$ & $19.0 \pm 14.7 \mathrm{~A}$ & $59.2 \pm 72.0 \mathrm{~B}$ & $54.3 \pm 33.9(9)$ \\
\hline
\end{tabular}

Means followed by the same letter are not significantly different at $P=0.05$, by the Tukey-Kramer test.

Table 2. East Lansing, Michigan: emerald ash borer larval density in green ash street trees and canopy thinning ratings of the same trees for one to three years after a single trunk injection of emamectin benzoate at a rate of $0.4 \mathrm{~g}$ ai/ inch dbh on September 27,2005 , or at 0.2 or 0.1 ai/2.54 cm dbh on May 21, 2007. Data are means \pm SD. Each treatment has 10 replications unless indicated otherwise under the mean \pm SD by $(n)$.

\begin{tabular}{|c|c|c|c|c|c|c|c|c|}
\hline Treatment & $\begin{array}{l}\text { Treatment } \\
\text { Dates }\end{array}$ & $\begin{array}{l}2006 \mathrm{dbh} \\
(\mathrm{cm})\end{array}$ & $\begin{array}{l}2006 \text { canopy } \\
\text { Thinning (\%) }\end{array}$ & $\begin{array}{l}2007 \text { canopy } \\
\text { thinning }\end{array}$ & $\begin{array}{l}2007 \text { Larvae } \\
\text { per } \mathrm{m}^{2}\end{array}$ & $\begin{array}{l}2008 \text { canopy } \\
\text { Thinning (\%) }\end{array}$ & $\begin{array}{l}2008 \text { larvae } \\
\text { per } \mathrm{m}^{2}\end{array}$ & $\begin{array}{l}2009 \text { canopy } \\
\text { thinning }(\%)\end{array}$ \\
\hline $\begin{array}{l}\text { Emamectin } \\
\text { trunk injection } \\
0.4 \mathrm{~g} \text { ai/inch } \mathrm{dbh}\end{array}$ & Sept. 2005 & $29.9 \pm 11.4$ & $7.3 \pm 8.9$ & $12.8 \pm 14.8$ & $0 \pm 0 \mathrm{~A}$ & $19.3 \pm 17.9 \mathrm{~A}$ & $0 \pm 0 \mathrm{~A}$ & $13.8 \pm 14 \mathrm{~A}$ \\
\hline $\begin{array}{l}\text { Emamectin } \\
\text { trunk injection } \\
0.2 \mathrm{~g} \text { ai/inch } \mathrm{dbh}\end{array}$ & May 2007 & $29.2 \pm 4.1$ & $11.8 \pm 1.6$ & $17.3 \pm 13.5(9)$ & $0 \pm 0 \mathrm{~A}(9)$ & $12.8 \pm 8.8 \mathrm{~A}(9)$ & $0 \pm 0 \mathrm{~A}(9)$ & $13.1 \pm 13.3 \mathrm{~A}(9)$ \\
\hline $\begin{array}{l}\text { Emamectin } \\
\text { trunk injection } \\
0.1 \mathrm{~g} \text { ai/inch } \mathrm{dbh}\end{array}$ & May 2007 & $38.2 \pm 7.3$ & $17.0 \pm 10.5$ & $11.4 \pm 15.9$ & $0 \pm 0 \mathrm{~A}$ & $29.8 \pm 29.4 \mathrm{~A}$ & $0 \pm 0 \mathrm{~A}(6)$ & $10.4 \pm 9.1 \mathrm{~A} \mathrm{(7)}$ \\
\hline Control & - & $28.7 \pm 10.6$ & $16.0 \pm 21.0$ & $28.5 \pm 27.9$ & $6.9 \pm 9.4 \mathrm{~B}$ & $51.3 \pm 30.2 \mathrm{~B}$ & $28.7 \pm 21.5 \mathrm{~B}$ & $58.1 \pm 33.2 \mathrm{~B}$ \\
\hline
\end{tabular}


Table 3. Adrian, Michigan: emerald ash borer larval density in green ash street trees and canopy thinning ratings of the same trees for 3-4 years after a single trunk injection of emamectin benzoate on June 22, 2006. Data are means \pm SD. Each treatment has 10 replications unless shown under the mean \pm SD as $(n)$.

\begin{tabular}{|c|c|c|c|c|c|c|c|c|}
\hline Treatment & $\begin{array}{l}\text { Treatment } \\
\text { dates }\end{array}$ & $\begin{array}{l}2008 \mathrm{dbh} \\
(\mathrm{cm})\end{array}$ & $\begin{array}{l}2006 \text { canopy } \\
\text { thinning }(\%)\end{array}$ & $\begin{array}{l}2007 \text { canopy } \\
\text { thinning }(\%)\end{array}$ & $\begin{array}{l}2007 \text { larvae } \\
\text { per } \mathrm{m}^{2}\end{array}$ & $\begin{array}{l}2008 \text { canopy } \\
\text { thinning }(\%)\end{array}$ & $\begin{array}{l}2008 \text { larvae } \\
\text { per } \mathrm{m}^{2}\end{array}$ & $\begin{array}{l}2009 \text { canopy } \\
\text { thinning }(\%)\end{array}$ \\
\hline $\begin{array}{l}\text { Emamectin } \\
\text { trunk injection } \\
0.4 \mathrm{~g} \text { ai/inch } \mathrm{dbh}\end{array}$ & June 2006 & $45.0 \pm 8.1 \mathrm{~A}^{\mathrm{z}}$ & $14.4 \pm 3.1 \mathrm{~A}$ & $11.1 \pm 6.0 \mathrm{~A}$ & - & $12.3 \pm 10.4 \mathrm{~A}$ & - & $7.2 \pm 6.7 \mathrm{~A}$ \\
\hline $\begin{array}{l}\text { Emamectin } \\
\text { trunk injection } \\
0.4 \mathrm{~g} \text { ai/inch } \mathrm{dbh}\end{array}$ & June 2006 & $43.1 \pm 12.2 \mathrm{~A}$ & $16.0 \pm 5.0 \mathrm{~A}$ & $11.6 \pm 6.5 \mathrm{~A}$ & $2.4 \pm 7.1 \mathrm{~A}$ & $13.0 \pm 12.7 \mathrm{~A}(9)$ & $0 \pm 0 \mathrm{~A}(9)$ & $20.0 \pm 8.0 \mathrm{~A}$ \\
\hline $\begin{array}{l}\text { Imidacloprid } \\
\text { trunk injection } \\
\text { + soil } \\
\text { imidacloprid }\end{array}$ & $\begin{array}{l}\text { June } 2007 \\
\text { + June } 2007 \text {, } \\
2008\end{array}$ & $38.4 \pm 9.8 \mathrm{~A}$ & $14.9 \pm 3.6 \mathrm{~A}$ & $12.0 \pm 4.9 \mathrm{~A}$ & - & $13.5 \pm 12.0 \mathrm{~A}$ & - & $23.9 \pm 10.1 \mathrm{~A}$ \\
\hline $\begin{array}{l}\text { Soil } \\
\text { imidacloprid }\end{array}$ & $\begin{array}{l}\text { June } 2006, \\
2007,2008\end{array}$ & $39.6 \pm 15.0 \mathrm{~A}$ & $14.2 \pm 5.7 \mathrm{~A}$ & $8.4 \pm 4.0 \mathrm{~A}$ & $3.6 \pm 6.8 \mathrm{~A}$ & $33.0 \pm 25.8 \mathrm{AB}$ & $\begin{array}{l}5.7 \pm 5.6 \\
\mathrm{AB}(4)\end{array}$ & $30.3 \pm 22.0 \mathrm{~A}$ \\
\hline Control 1 & - & $43.4 \pm 16.9 \mathrm{~A}$ & - & $12.0 \pm 15.1 \mathrm{~A}$ & - & $58.3 \pm 26.5 \mathrm{BC}$ & $\begin{array}{l}23.6 \pm 39.4 \\
\text { B }(8)\end{array}$ & $89.5 \pm 13.4 \mathrm{~B}$ \\
\hline Control 2 & - & $44.7 \pm 11.2 \mathrm{~A}$ & $15.6 \pm 5.4 \mathrm{~A}$ & $10.3 \pm 7.0 \mathrm{~A}$ & $6.2 \pm 6.6 \mathrm{~A}$ & $64.0 \pm 29.3 \mathrm{C}$ & $\begin{array}{l}27.7 \pm 28.9 \\
\text { B }(7)\end{array}$ & $84.6 \pm 12.0 \mathrm{~B}$ \\
\hline
\end{tabular}

${ }^{\mathrm{z}}$ Means followed by the same letter are not significantly different at $P=0.05$, by the Tukey-Kramer test.

Ash trees receiving an annual basal drench of imidacloprid or a combination of an imidacloprid basal drench and an imidacloprid trunk injection also appeared healthy as determined by canopy thinning ratings at the end of the Adrian test, but significantly more EAB larvae $\left(5.7\right.$ per $\left.\mathrm{m}^{2}\right)$ were found in imidacloprid-treated trees compared with emamectin benzoate-treated trees $\left(0.0\right.$ per $\left.\mathrm{m}^{2}\right)$.

Protection of ash trees for 2-4 years following a single insecticide treatment completely changes the prognosis for ash street trees and shade trees in North America after invasion of emerald ash border. Up until this time, insecticide treatment was reserved for only the most valuable trees because of the high cost of making frequent trunk injections. The multiple-year protection documented in this study reduces the projected cost of saving ash trees by at least $50 \%$, bringing treatments well within the range of many homeowners and some cities or other municipalities. For example, one can compare the cost of hiring an arborist to treat a $31.4 \mathrm{~cm}$ dbh ash tree with annual trunk injections of IMA-jet (imidacloprid) at the $8 \mathrm{ml} / 2.54 \mathrm{~cm}$ dbh rate, to the cost of hiring the same arborist to treat every other year or every fourth year with TREE-äge (emamectin benzoate) at the $0.4 \mathrm{~g}$ ai $/ 2.54 \mathrm{~cm}$ dbh rate. At the time of this writing the cost of the imidacloprid insecticide to the arborist is USD \$23.92 per year, the cost of the emamectin benzoate insecticide is $\$ 26.13$ per year when treating every third year, and $\$ 17.42$ when treating every fourth year. Labor costs vary depending on the arborist, the number and size of trees being treated, and the location of the property. If one adds a labor charge of $\$ 50.00$ per treatmentvisit for the $31.4 \mathrm{~cm}$ dbh tree, then the total average cost per year over a three-year period would be \$73.92/year for annual imidacloprid trunk injections, $\$ 51.13 /$ year for emamectin benzoate injections made every third year, and $\$ 34.09 /$ year for emamectin benzoate injections made every fourth year. This brings the cost of trunk injections into a much more practical range for homeowners, especially when weighed against the cost of tree removal which may be more than $\$ 1,500$ for a large tree $(62.8 \mathrm{~cm} \mathrm{dbh})$.
Data from Troy, East Lansing, and Adrian, MI, indicate most of the ash trees in cities along the leading edge of the contiguous EAB invasion front will perish within five years of when the first trees are found to die from EAB. This was certainly true for Troy, MI, and much of the Detroit Metropolitan area where the first ash trees began to die in 2004. By 2009 all of the ash trees were dead except ones that were protected with insecticide treatments or where young trees have sprouted from the stumps of dead ones. Sprouting ash trees and the germination of ash seed will guarantee the survival of EAB, but populations will be much smaller after the initial five to eightyear period when unprotected ash trees perish. This means the remaining ash trees will be easier to protect with insecticides.

Acknowledgments. We appreciate the assistance of Terrance Davis for supervising the field research, and the Cities of Troy, East Lansing, and Adrian, for assisting with branch sampling. This research was partially supported by Arborjet, Inc., Syngenta Crop Science, and the Michigan Agricultural Experiment Station.

\section{LITERATURE CITED}

Bray, A.M., L.S. Bauer, R.A. Haack, T. Poland, and J.J. Smith. 2007. Invasion Genetics of Emerald Ash Borer (Agrilus planipennis Fairmaire) in North America. In: Proceedings from the Third Workshop on Genetics of Bark Beetles and Associated Microorganisms, B. Bentz, A. Cognato, and K. Raffa (Eds.).

Cappaert, D., D.G. McCullough, T.M. Poland, and N.W. Siegert. 2005. Emerald ash borer in North America: a research and regulatory challenge. American Entomologist 51:152-165.

Haack, R.A., E. Jendek, H. Liu, K.R. Marchant, T.R. Petrice, T.M. Poland, and H. Ye. 2002. The emerald ash borer: a new exotic pest in North America. Newsletter of the Michigan Entomological Society 47:1-5.

Herms, D.A., D.G. McCullough, D.R. Smitley, C.S. Sadof, R.C. Williamson, and P.L. Nixon. 2009. Insecticide options for protecting ash trees from emerald ash borer. North Central IPM Center Bulletin. 12 pp. 
Kreutzwiser, D.R., K.R. Good, D.I. Chartrand, T.A. Scarr, and D.G. Thompson. 2008. Are leaves that fall from imidacloprid-treated maple trees to control Asian longhorned beetles toxic to non-target decomposer organisms? Journal of Environmental Quality 37:639-646.

Marshall, J.M., A.J. Storer, I. Fraser, and V.C. Mastro. 2009. A predictive model for the detection of Agrilus planipennis larvae in ash trees. Entomologia Experimentalis et Applicata 133:1-16.

Poland, T.M., and D.G. McCullough. 2006. Emerald ash borer: invasion of the urban forest and the threat to North America's ash resource. Journal of Forestry 104:118-124.

SAS 2003. SAS 9.1. SAS Institute Inc. Cary, NC.

Smitley, D., T. Davis, and E. Rebek. 2008. Progression of ash canopy thinning and dieback outward from the initial infestation of emerald ash borer (Coleoptera: Buprestidae) in Southeast Michigan. Journal of Economic Entomology 101:1643-1650.

Smitley, D.R., E.J. Rebek, R.N. Royalty, T.W. Davis, and K.F. Newhouse. 2010. Protection of individual ash trees from emerald ash borer (Coleoptera: Buprestidae) with basal soil applications of imidacloprid. Journal of Economic Entomology 103:119-126.

USDA APHIS. 2010. Cooperative Emerald Ash Borer Project. <http:// www.emeraldashborer.info/files/MultiState_EABpos.pdf $>$.

David R. Smitley (corresponding author)

Department of Entomology

Michigan State University

East Lansing, MI 48824, U.S.

smitley@msu.edu

Joseph J. Doccola

Arborjet, Inc.

99 Blueberry Hill Road

Woburn, MA 01801, U.S.

joedoccola@arborjet.com

David L. Cox

Syngenta Crop Protection, Inc.

14446 Huntington Rd

Madera, CA 93636, U.S.

david.cox@syngenta.com
Résumé. Des frênes de Pennsylvanie (Fraxinus pennsylvanica Marsh.) de rue de 25 à $45 \mathrm{~cm}$ de DHP ont été injectés au tronc avec du benzoate d'emamectine à des taux de 0,1 à $0,6 \mathrm{~g}$ d'ingrédient actif par 2,54 cm de DHP, et ce au Michigan en 2005 ou 2006. La condition de santé des arbres a été suivie en regard des taux de densité de la cime et de dépérissement jusqu'à quatre ans après un traitement unique. Des échantillons de branches ont été récoltées en automne et l'écorce enlevée pour faire un décompte des larves d'agrile du frêne pour la plupart des traitements durant la même période. Une injection unique dans le tronc de benzoate d'emamectine à des taux de 0,1 ou $0,4 \mathrm{~g}$ d'ingrédient actif a produit un contrôle à $100 \%$ des larves d'agrile du frêne sur 98 des 99 arbres traités durant une période de 2 à 3 ans. Les cimes sont demeurées similaires chez les arbres traités durant une période de 2 à 4 ans après l'injection dans le tronc tandis que plus de 50\% des arbres témoins mouraient au cours de la même période. Les frênes qui ont reçu une combinaison d'imidacloprid par injection dans le tronc et par injection dans le sol ou par injection annuelle dans le sol avaient des cimes similaires, mais plus de larves ont été découvertes dans les branches des arbres qui recevaient des injections annuelles dans le sol.

Zusammenfassung. Grüne Eschen als Straßenbäume in der Größe von $25-45 \mathrm{~cm}$ Stammdurchmesser wurden im Stamm mit Emamectin Benzoat in Raten von 0,10-0,60 g ai/2,54 cm Stammdurchmesser an drei verschiedenen Standorten in Michigan, U.S. injiziert. Die Baumgesundheit wurde überwacht durch jährliches Ausdünnen der Krone und Bewertung der Totholzbildung für bis zu 4 Jahren nach einer Behandlung. Im Herbst wurden Astproben gesammelt und bei den moisten Behandlungen auch die Rinde entfernt, um die Larven des Eschenbohrers im gleichen Zeitraum zu zählen. Eine einzelne Stamminjektion mit Emamectin Benzoat mit Raten von 0,1, 0,2 und 0,4 g ai ergab eine $100 \%$ Kontrolle der Larven in 98 von 99 behandelten Bäumen in 2-3 Jahren. Die Kronenbewertung bei behandelten Bäumen blieb über für 2-4 Jahre nach der Behandlung gleich, während $>50 \%$ der kontrollierten Bäume im gleichen Zeitraum abstarben. Eschen, die eine Kombination aus ImidaclopridStamm-Injektion und Imidacloprid-Wurzelaufguss oder einen jährlichen Imidacloprid-Wurzelaufguss erhielten, hatten ähnliche Kronenbilder aber es wurden mehr Larven in Ästen von Bäumen gefunden, die einen jährlichen Imidacloprid-Wurzelaufguss erhielten.

Resumen. Árboles de fresno (Fraxinus pennsylvanica Marsh.) de tamaños de 25 a $45 \mathrm{~cm}$ de DAP fueron inyectados al tronco con benzoato de emamectin a tasas de $0.10-0.60 \mathrm{~g} / 2.54 \mathrm{~cm}$ de DAP en tres localidades de Michigan en 2005 y 2006. Fue monitoreada la salud de los árboles por muerte descendente y aclareos de copa anuales por cuatro años después del tratamiento. Se colectaron muestras de ramas en el otoño y la corteza removida para contar las larvas del barrenador esmeralda del fresno para los tratamientos en el mismo período. Un solo tratamiento de inyección al tronco de benzoato de emamectin a una tasa de $0.1,0.2$ o $0.4 \mathrm{~g}$ dio $100 \%$ de control de larvas del barrenador esmeralda del fresno en 98 de 99 árboles tratados para 2-3 años. Los estados de las copas para los árboles tratados permanecieron similares para 2-4 años después de la inyección, mientras que $>50 \%$ de los árboles tratados murió durante el mismo período de tiempo. Los fresnos que recibieron una combinación de una inyección al tronco de imidacloprid y una zanja basal de imidacloprid o un tratamiento anual de zanja con imidacloprid tuvo estados de copa similares, pero se encontraron más larvas en ramas de árboles que recibieron zanjas anuales. 